\title{
Stromal microsporidiosis: a differential for disciform keratitis
}

\author{
Anirban Dutta, Sujata Das, Smruti Rekha Priyadarshini
}

Cornea and Anterior Segment, LV Prasad Eye Institute Bhubaneswar Campus, Bhubaneswar, Orissa, India

\section{Correspondence to} Dr Smruti Rekha Priyadarshini; rekha.smruti@gmail.com

Accepted 14 July 2020

\section{DESCRIPTION}

A 19-year-old woman presented with intermittent redness, watering, pain and diminution of vision in her right eye for 6 months. There was no history of ocular trauma or systemic comorbidities. She was referred to us with a diagnosis of microbial keratitis and was on topical antibiotic eyedrops hourly for the past 7 days without improvement. The visual acuity of her right eye was counting fingers at $1 \mathrm{~m}$. Examination revealed an epithelial defect of $1 \times 1$ $\mathrm{mm}$ with underlying disciform deep stromal infiltrate measuring $4 \times 3.6 \mathrm{~mm}$ with a streak hypopyon. No keratic precipitates were noted (figure 1). The left eye was unremarkable on examination.

Corneal scrapings were obtained and subjected to $10 \%$ potassium hydroxide $(\mathrm{KOH})$ and Gram's stain. Reports were negative and antibiotics were continued. As there was no desirable response over the next 48 hours, corneal biopsy was performed which turned out negative. A differential diagnosis of herpes simplex virus (HSV) stromal keratitis was considered because of long standing history, clinical picture and unresponsiveness to antibiotics. An anterior chamber tap for PCR was done which was also negative for HSV. On the basis of clinical suspicion of HSV, oral acyclovir $400 \mathrm{mg}$ five times per day and topical prednisolone acetate (1\%) eight times per day was initiated. On observing no clinical improvement, she underwent a therapeutic penetrating keratoplasty. Back button scraping of the corneal button revealed microsporidial spores on staining (figure 2). Histopathological examination of the corneal button revealed scattered spores which further confirmed the diagnosis. The patient was symptomatically better, visual acuity improved to $20 / 200$, and there was no evidence of recurrence till her last visit.

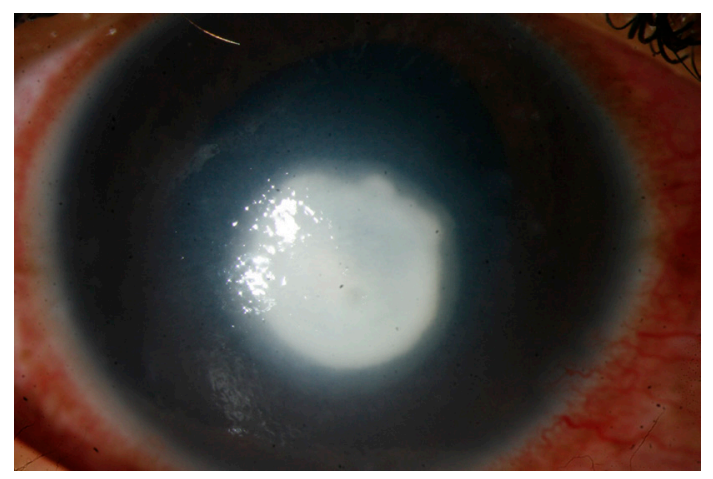

Figure 1 Right eye slit lamp photo in diffuse illumination showing a deep stromal infiltrate involving the central cornea.

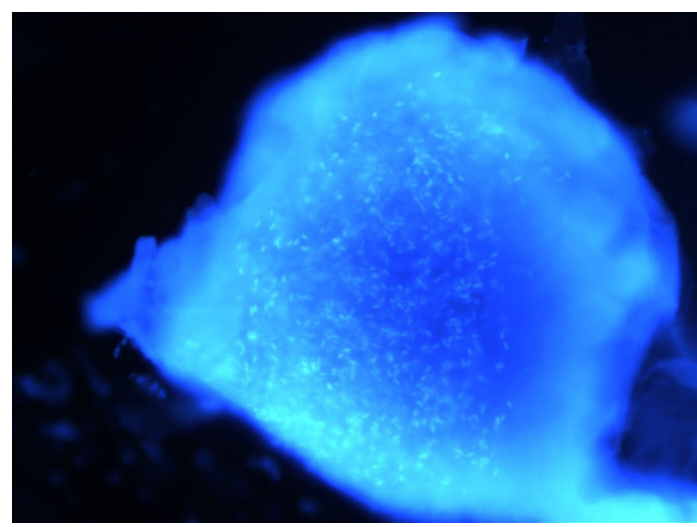

Figure 2 10\% Potassium hydroxide+calcofluor white smear showing microsporidial spores (40x magnification).

Microsporidia are slow-growing eukaryotes which cause an insidious infection. ${ }^{1}$ Joseph et al noted calcofluor white $(\mathrm{CFW})+\mathrm{KOH}$ and modified Ziehl Neelsen staining to be the most efficient in microsporidia detection, followed by the Gram and Giemsa stains. ${ }^{2}$ They recommended calcofluor white as the stain of choice for identifying microsporidia. As these organisms grow on tissue culture, role of culture media is limited. ${ }^{2}$ PCR is a rapid, sensitive, scalable and quantifiable test which can also differentiate between the different species of microsporidia. Joseph et al found that PCR had a sensitivity of $83 \%$ and specificity of $98 \%$, hence making it a useful adjunct to routine microbiological workup. ${ }^{3}$

Microsporidia as an emerging cause of stromal keratitis have been described by Vemuganti et al. ${ }^{4}$ Microsporidial stromal keratitis may present as an indolent ulcer mimicking HSV stromal keratitis. ${ }^{5}$ Coexistence of HSV has been reported in diagnosed cases of microsporidial stromal keratitis associated with granulomatous inflammation. ${ }^{6}$ It is usually refractory to medical treatment and may recur in lamellar corneal transplants. ${ }^{4}$

\section{Patient's perspective}

I had consulted in the Cornea Services for diminution of vision in my right eye. I was told that the disease in my right eye is chronic in nature and was due to an infection. I was advised to undergo relevant investigations and subsequent medical and surgical therapy. I am happy that my vision has improved and am symptomatically better. 


\section{Learning points}

- A long standing disciform keratitis unresponsive to topical treatment should have microsporidiosis as a differential diagnosis.

- Stromal microsporidiosis is refractory to medical treatment and must be managed surgically with a full thickness transplant.

- Repeated microbiological workups can turn out to be negative in these cases.

Diagnosis is mostly by smear $(\mathrm{KOH}+\mathrm{CFW})$, and at times by PCR. ${ }^{23}$ In our case, where smear result was unremarkable and interventional methods like corneal biopsy also failed, we were left with no choice other than performing therapeutic keratoplasty for diagnosis and treatment. The back button scraping and histopathology report helped in establishing the diagnosis.

Contributors AD: Manuscript writing and literature review. SRP: Concept, design and editing. SD: Diagnosis, management and editing.
Funding The authors have not declared a specific grant for this research from any funding agency in the public, commercial or not-for-profit sectors.

Competing interests None declared.

Patient consent for publication Obtained.

Provenance and peer review Not commissioned; externally peer reviewed.

\section{REFERENCES}

1 Sabhapandit S, Murthy SI, Garg P, et al. Microsporidial stromal keratitis: clinical features, unique diagnostic criteria, and treatment outcomes in a large case series. Cornea 2016;35:1569-74.

2 Joseph J, Murthy S, Garg P, et al. Use of different stains for microscopic evaluation of corneal scrapings for diagnosis of microsporidial keratitis. J Clin Microbiol 2006;44:583-5.

3 Joseph J, Sharma S, Murthy SI, et al. Microsporidial keratitis in India: 16S rRNA genebased PCR assay for diagnosis and species identification of microsporidia in clinical samples. Invest Ophthalmol Vis Sci 2006;47:4468-73.

4 Vemuganti GK, Garg P, Sharma S, et al. Is microsporidial keratitis an emerging cause of stromal keratitis? A case series study. BMC Ophthalmol 2005;5:19.

5 Sharma S, Das S, Joseph J, et al. Microsporidial keratitis: need for increased awareness. Surv Ophthalmol 2011:56:1-22.

6 Mittal R, Balne PK, Sahu S, et al. Coexistence of herpes simplex virus infection in microsporidial stromal keratitis associated with granulomatous inflammation. Indian J Ophthalmol 2017;65:276-81.

Copyright 2020 BMJ Publishing Group. All rights reserved. For permission to reuse any of this content visit

https://www.bmj.com/company/products-services/rights-and-licensing/permissions/

BMJ Case Report Fellows may re-use this article for personal use and teaching without any further permission.

Become a Fellow of BMJ Case Reports today and you can:

Submit as many cases as you like

Enjoy fast sympathetic peer review and rapid publication of accepted articles

- Access all the published articles

Re-use any of the published material for personal use and teaching without further permission

Customer Service

If you have any further queries about your subscription, please contact our customer services team on +44 (0) 2071111105 or via email at support@bmj.com.

Visit casereports.bmj.com for more articles like this and to become a Fellow 